See discussions, stats, and author profiles for this publication at: https://www.researchgate.net/publication/317335683

\title{
A Comparative Analysis of Firm Co-Location Behavior in the Detroit Metropolitan Area
}

Article in Industry and Innovation · June 2017

DOI: 10.1080/13662716.2017.1334539

CITATIONS

3

3 authors, including:

Elizabeth A. Mack

Michigan State University

76 PUBLICATIONS 1,272 CITATIONS

SEE PROFILE
READS

81

Kevin Credit

National University of Ireland, Maynooth

15 PUBLICATIONS 69 CitATIONS

SEE PROFILE 
A Comparative Analysis of Firm Co-Location Behavior in the Detroit Metropolitan Area

Elizabeth A. Mack

Department of Geography, Environment, and Spatial Sciences

Michigan State University

*Corresponding Author: emack@msu.edu

Kevin Credit

Department of Geography, Environment, and Spatial Sciences

Michigan State University

Email creditke@msu.edu

Matthew Suandi

Department of Economics

Michigan State University

Email: suandima@msu.edu 


\begin{abstract}
Multinational enterprises (MNEs) now exhibit knowledge-seeking behaviors which are critical to maintain or gain a competitive advantage. Emerging work about the interaction between MNEs, space, and place also highlights the need for finer scale research to understand the strategy and knowledge exchange of MNEs, which remains limited to this point. To address this need for finegrained analyses of firm co-location behavior, this paper uses point-level data to test hypotheses about the co-location behavior of three types of manufacturing firms in the Detroit metropolitan area. Variations in this behavior highlight that foreign rather than domestic firms may be the primary source of knowledge spillovers, which speaks to the internationalization of manufacturing activity in the region over time. New domestic standalone ventures appear to have been crowded out from cluster activities, suggesting a policy opportunity to integrate new standalone ventures into collaborative ventures with other firms in the region.
\end{abstract}

Keywords: co-location, clusters, firm location, knowledge-spillovers, multi-national enterprises (MNEs) 
Multinational enterprises (MNEs) are a critical component to regional competitiveness because of the reciprocal relationship between these firms and the economic vitality of regions in which they are located (Narula and Santangelo 2012). While a significant amount of attention has been dedicated to understanding the factors that retain and attract these firms (Dunning 1988; Mudambi 1995; Barrios et al. 2012), it is also recognized that the orientation of MNEs is evolving from location factors based on cost and resources to include or even emphasize knowledge activities (Dunning 1998). The shift to knowledge-seeking behavior by MNEs (Cantwell 1989; Almeida and Phene 2004; Kappen 2011; Cantwell and Mudambi 2011) has important implications for the role of space, place, and local context in shaping the location of MNE activities (Beugelsdijk, McCann, and Mudambi 2010). This is particularly true concerning co-location, which increases firms' exposure to knowledge spillovers (Lamin and Livanis 2013).

Knowledge spillovers have long been acknowledged as a benefit of agglomeration (Marshall 1920), encouraging the physical co-location of firms in geographic space (Lamin and Livanis 2013). Studies have also found that these spillovers are a highly localized phenomenon (Jaffe, Tratjenberg, and Henderson 1993; Anselin, Varga, and Acs 1997; Rosenthal and Strange 2003) whose benefits can vary over time (Jaffe, Tratjenberg, and Henderson 1993). Prior work has also acknowledged that the co-location behavior of firms can reveal important information about MNE firm strategy and the use of information to mitigate information asymmetries (Zaheer 1995; Zaheer 2002), acquire new capabilities to catch-up with competitors (Lamin and Livanis 2013), or prevent knowledge spillovers that would disclose proprietary information (Cantwell and Mudambi 2011).

Given these rationales for co-locating in geographic space to gain access to - or even prevent - knowledge spillovers, the propensity to co-locate is likely to vary by type of venture 
analyzed (Bosma, Stel, and Suddle 2008; Jofre-Monseny et al. 2011). Foreign firms, for example, may co-locate to seek out local connections and networks to mitigate their liability of foreignness (Zaheer 1995). Local firms may co-locate to gain access to resources to mitigate the liability of newness (Stinchcombe 1995) and the limited resources of smaller firms (Coombs, Mudambi, and Deeds 2006). Established, but lagging, domestic firms may co-locate to gain access to knowledge spillovers that will permit them to upgrade technology and other competencies in a catch-up strategy (Lamin and Livanis 2013). Industry leaders may also choose not to co-locate in an act of strategic deterrence to prevent leakages of proprietary knowledge (Cantwell and Mudambi 2011). Given temporal variations in the benefits derived from knowledge spillovers, these co-location tendencies are also likely to evolve over time as the needs and competencies of firms change.

The localized nature of knowledge spillovers, the variation in firm strategy for gaining access to knowledge spillovers, and varying information needs of firms over time highlight a need for sub-regional analyses of the co-location behavior of MNEs, and comparative work about the co-location behavior of various firm types. While prior sub-national evaluations of co-location behavior have revealed important information about the strategic behavior of firms (Lamin and Livanis 2013; Alcácer and Chung 2014), more detailed analyses are necessary to understand the micro-foundations of co-location given the opportunity they present for knowledge spillovers (Lamin and Livanis 2013), and the highly localized nature of knowledge spillovers (Anselin, Varga, and Acs 1997). Emerging work about the interaction between MNEs, space, and place also highlights the need for finer scale research to understand the strategy and knowledge exchange of MNEs (Narula and Santangelo 2009). Unfortunately, there is a limited body of work from which to draw about the sub-regional location trends of MNEs (McCann and Mudambi 2005). 
To address a need for more fine-grained analyses of firm co-location behavior, the goal of this paper is to leverage annual point-level data from 1990-2010 to test hypotheses about the colocation behavior of three types of manufacturing firms (foreign multinationals, domestic multiestablishment firms, and domestic standalone firms) in the Detroit metropolitan area, home to a world famous automobile cluster. Despite the spread of auto-manufacturing (particularly assembly-oriented activities) to other parts of the United States from this key node of activity (Klier and McMillan 2008), recent work highlights the continued importance of Detroit from a knowledge and innovation perspective (Hannigan, Cano-Kollmann, and Mudambi 2015). Analytical results reveal distinct differences in co-location tendencies across the three firm types over time. Variations in co-location behavior reveal that foreign rather than domestic firms may be an increasingly important source of knowledge spillovers for both new foreign and new branches of domestic multi-establishment firms. These results thus speak to the internationalization of manufacturing activity in the region over time, and the likely collaboration of firms from different countries in more recently established centers of excellence. New domestic standalone ventures appear to have been crowded out from cluster activities; they do not co-locate with either foreign or domestic multi-establishment firms. This suggests a policy opportunity to integrate new standalone ventures into collaborative ventures with larger manufacturers, both foreign and domestic, in the region.

\section{MNEs and Co-location}

The OLI framework based on the triumvirate of ownership (O), location (L), and internationalization (I) (Dunning 1977) has been used for some time as an analytical framework in which to understand the activities of multinational companies. Based on this framework, studies have grouped the factors that impact the location decisions of MNEs into three groups: 
infrastructure, location-specific risk factors, and government policy (Dunning 1988; Mudambi 1995). Evaluations of these factors have found labor costs and corporate taxes to be comparatively more important, while policies are suggested to have an indirect, yet enduring effect on levels of MNE investment that can persist even after policies expire (Mudambi 1995). Other country-level studies have found that incentives play an influential role in the location of MNE activity (Friedman, Gerlowski, and Silberman 1992; Dunning 1998; Buettner and Ruf 2007), as do national-scale levels of taxation (Barrios et al. 2012). Work has also highlighted less objective factors related to managerial preferences as a driving factor behind MNE location decisions (Schotter and Beamish 2013).

While work on MNEs has illustrated renewed interest on the "L" dimension of MNE activities (Narula and Santangelo 2012), there has been comparatively less work on the location behavior of MNEs at the regional level and within cities (McCann and Mudambi 2005). Unfortunately, in the context of international business studies, "local" often refers to nation states (Meyer, Mudambi, and Narula 2011), which is an insufficient level of analysis to evaluate the micro-foundations of multinational enterprises engaged in knowledge activities. This level of analysis is also incapable of unraveling the heterogeneous local context within large countries such as India, China, and Mexico which represent important locations of MNE activity.

The evolution of the global economy has changed the rationale behind the location decisions of MNE activities from resource and cost-oriented considerations to those that are based on the institutional environment and the potential various locations offer for upgrading process quality and knowledge assets (Dunning 1998). This shift to knowledge-seeking behavior by MNEs (Cantwell 1989; Almeida and Phene 2004; Kappen 2011; Cantwell and Mudambi 2011) has important implications for the role of space, place, and local context in shaping the location of 
MNE activities (Beugelsdijk, McCann, and Mudambi 2010). This is particularly true concerning co-location, which increases firms' exposure to knowledge spillovers (Lamin and Livanis 2013).

\section{Hypotheses about Co-Location Behavior}

Knowledge spillovers have long been recognized as a driving force behind the agglomeration or co-location of firms in geographic space (Marshall 1920). These spillovers occur via localized informal interactions such as business meetings, changes in employment, and interactions between buyers and suppliers (Alcacer and Chung 2007), which endow benefits in the form of information that provide the economic justification for co-location. While prior work has provided important information about knowledge spillovers at the country level (Alcacer and Chung 2007; Chang and Xu 2008), and between foreign and domestic firms at the city level in an emerging market context (Lamin and Livanis 2013), more work at the sub-national level is needed to understand co-location of firms in a comparative context over both space and time. This type of work is particularly critical given the highly localized nature of knowledge spillovers (Anselin, Varga, and Aces 1997; Rosenthal and Strange 2003). While research results produce varying distance estimates over which spillovers can occur, Rosenthal and Strange (2003) found that spillovers were most pronounced within 1 mile of businesses in specific manufacturing industries (NAICS 34 and 35). The need for spillovers may also change over time as the liability of foreignness of foreign enterprises diminishes over time (Cantwell and Mudbami 2011).

Aside from basic access to information, comparative work has highlighted the complexities behind the co-location behavior of domestic compared to foreign firms, particularly as it relates to firms' strategies to gain access to resources or to mitigate information asymmetries about locations (Lamin and Livanis 2013). Foreign firms, for example, are known to co-locate near domestic firms to minimize the liability of foreignness (Zaheer 1995) which helps foreign firms gain social and 
relational knowledge about places (Zaheer 2002). Thus, it is hypothesized that if efforts to minimize the liability of newness dominate firm location decisions, then:

H1: New foreign firms will co-locate with existing multi-establishment domestic firms.

Arguments may also be made for the co-location of new foreign firms with existing foreign firms. Here, cultural familiarity may play an "enclave effect" role in the co-location behavior of firms. From this perspective, new foreign firms may be more likely to locate near existing foreign firms, which provide an incubation effect stemming from improved knowledge sharing, facilitated by cultural similarity and/or similar logistical problems (and solutions) for operating a foreign firm in a new setting (Lamin and Livanis 2013). Thus, a follow up hypothesis to the first hypothesis above is that if the enclave effect dominates the need to mitigate the liability of foreignness, then:

H2: New foreign firms will co-locate with existing foreign firms.

However, the informational needs and subsequent co-location behavior of firms is also likely to change over time. Chung and Song (2004) highlight that the benefits to co-location will vary over time, particularly for firms with prior investments in regions and thus more knowledge of regional customs and resources. Cantwell and Mudambi (2011) highlight this evolutionary aspect of foreign enterprises and acknowledge that the status of foreign firms can change from "outsider" status to "insider" status as they become more locally embedded. If foreign firms become accustomed to operating in a particular area over time, it is expected that the liability of 
foreignness will diminish, as will the propensity to co-locate with other foreign firms. Based on this anticipated behavior, the following hypothesis is proposed:

H3: The propensity of new foreign firms to co-locate with existing foreign firms will diminish over time.

Comparative work on the co-location of domestic and foreign firms, however, highlights that co-location is not just important to foreign firms, but also to domestic firms, particularly if the competitive position of domestic firms lags those of foreign competitors. For the case of Detroit, where manufacturing firms have experienced intense periods of competition from foreign competitors, the location behavior of domestic firms compared to new and existing foreign competitors provides an interesting context in which to examine co-location behavior that may reflect an effort to "catch-up" in an established market (Lamin and Livanis 2013). This is certainly the case for auto-manufacturing companies in Detroit, which experienced an intense period of industry competition in the late 1980's and early 1990's as foreign competitors gained market share by producing more innovative and higher-quality cars. Thus, the following hypothesis will be tested about the co-location behavior of domestic multi-establishment firms:

H4: In times of stress for domestic manufacturers, new branches of multi-establishment firms will co-locate with existing foreign firms.

That said, there are several reasons that firms may choose not to co-locate with other firms. Cantwell and Mudambi (2011) is one of the first studies to note that firms may not co-locate to protect proprietary knowledge and prevent knowledge leakages in an act of strategic deterrence. Thus, industry leaders (foreign or domestic) may not co-locate with other firms to protect 
proprietary knowledge. In times of increasing competition from foreign competitors and weak competitive position of domestic firms, such as the bailout of GM and Chrysler in 2008, domestic manufacturing firms may opt not to co-locate with foreign firms to prevent knowledge spillovers. Foreign firms at this time may also take steps to prevent the co-location of domestically based firms to protect their competitive advantage. In the context of this study, this type of strategic behavior should be most evident in the later years of the study period, when foreign competition intensified. By 2007, Toyota had overtaken GM as the world's number one automaker; they did this by satisfying customer demand for smaller cars which went unfilled by U.S. automakers (Amadeo 2016). Thus, while co-location with foreign firms provides evidence that domestic firms are trying to gain access to knowledge spillovers to catch-up to foreign competitors, a lack of support for hypothesis four would provide evidence about a lack of co-location in an act of strategic deterrence to prevent knowledge spillovers of proprietary domestic firm knowledge.

Brand new domestic firms are anticipated to co-locate with other firms for very different reasons than branches of foreign firms or established multi-establishment firms. While a "catchup" rationale for co-location is likely to be more important for new branches of mature multiestablishment firms, brand new standalone businesses are likely to locate near other firms to mitigate the liability of newness (Stinchcombe 1965). From this perspective, a need for resources and access to networks is a likely explanation for the co-location of new domestic standalone firms. Established business clusters also provide a critical mass of entrepreneurs, which has been noted to be an important factor for fostering a culture of entrepreneurship that promotes higher rates of subsequent entrepreneurship (Glaeser, Kerr, Ponzetto 2009), as well as spin-off activity (Carlsson and Mudambi 2003). Based on these benefits and the need to co-locate to mitigate the liability of newness, the following hypothesis is proposed: 
H5: New domestic standalone firms will co-locate with existing domestic multi-establishment firms.

In this hypothesis, the emphasis is on existing domestic multi-establishment firms, since they likely provide the best networks and resources for domestically oriented firms.

\section{Study Area}

To test the hypotheses described above, spatio-temporal variations in firm co-location activity across different firm types with varied international orientations are examined over the 1990-2010 study period for the Detroit metropolitan area. The Detroit metropolitan area is defined as containing the counties of Macomb, St. Clair, Livingston, Wayne, Lapeer, and Oakland based on the 2010 definition of metropolitan statistical areas provided by the Office of Management and Budget (OMB). Auto production in Detroit dates back to the start of the twentieth century with the construction of the city's first manufacturing plant by Ransom E. Olds in 1899, which was followed by Ford Motor company four years later in 1903 and the Chrysler Corporation in 1925 (Weber 2013). Since its beginnings in Detroit, the Ford Motor company relocated to the suburb of Dearborn, Michigan; Chrysler also relocated from its original downtown Detroit headquarters and is located currently in Auburn Hills, Michigan (Weber 2013), 34 miles north of Detroit. The suburbs of Detroit are also home to several technical centers of foreign auto companies. The Nissan Technical Center for North America is located in Farmington Hills (Nissan 2016). Visteon Corporation, which specializes in automotive electronics, has their technical headquarters in Van Buren Township, Michigan (Visteon 2017) about 34 miles outside of Detroit. Thus, while the analysis in this paper focuses on auto-manufacturing and related industries, the automobile industry is a key driver of economic activity, especially given its historical importance to the region. 
Figure 1 underscores the historical - and continuing - importance of the manufacturing sector for new starts in Detroit. While new manufacturing business activity has declined after 2000 for domestic firms, a high proportion of new foreign establishments in the region - an average of $20.8 \%$ for the entire study period - are classified in NAICS categories 32 and 33, with increasing percentages after the year 2000. This concentration of multinational manufacturing firm formation activity in Detroit highlights the need to investigate the location behavior of manufacturing businesses further in this historically important region.

\section{Figure 1 here}

Aside from the industrial importance of the auto cluster, the time period is also interesting because it includes several critical years in the manufacturing industry. The twenty-year period includes the years of decline that began in the 1980s and continued through the 1990s with the arrival of foreign assembly plants in the United States (Klier and McMillen 2008). It includes the Internet revolution in the early 2000s, as well as the years prior to and immediately following the government bailout of GM and Chrysler in 2008 and 2009 (Weber 2013).

\section{Data}

Information about the locations of businesses in the auto cluster is drawn from the National Establishment Time Series (NETS), which is a point-level database that covers all establishment ${ }^{1}$ activity in Detroit

between 1990 and 2010 (Walls \& Associates 2013). The database includes a variety of information about the physical locations of businesses and industry information based on the North American Industrial Classification System (NAICS). It also contains an important field that indicates if a company is a standalone business, headquarters, branch, or a division. For the branch

\footnotetext{
${ }^{1}$ Establishments are a single physical location at which business activities are conducted. Therefore, these data contain higher resolution information than company-based data.
} 
establishments, associated headquarters information is provided. Due to the way the data are collected, reporting only the most recent geographical location of the business at the time of database release, the universe of firms used in this study contains new entrants that have not relocated at any point in the study period. This preserves the original location of both new entrants and existing businesses to better understand the co-location activity of new entrants with existing businesses at their original point of entry.

Co-location activity of three kinds of new business activity (foreign multinationals, domestic multi-establishment firms, and domestic standalone firms) and three kinds of existing business activity (foreign multinationals, domestic multi-establishment firms, and domestic standalone firms) are analyzed in this paper, providing nine possible combinations of co-location behavior. The new or existing status of businesses was determined by a field in the NETS database which indicates the year a firm started. Foreign multinationals are defined as establishments whose headquarters are located in a country outside of the United States. Domestic multi-establishment firms are non-foreign owned companies with headquarters and/or branch establishments in the Detroit region. Domestic standalone firms are local non-branch, standalone businesses with no known international ties. Company names in the database of new and existing ventures extracted for this analysis were crosschecked with the literature referencing key suppliers and foreign automakers connected to Detroit (Hannigan, Cano-Kollmann, and Mudambi 2015) to enhance the robustness of results.

The analysis that follows emphasizes manufacturing businesses in Detroit. In this paper, manufacturing businesses are defined as North American Industrial Classification Industries (NAICS) 32 and 33. This definition includes core components of the auto cluster (HBS 2014), but incorporates a wider range of businesses considered in prior studies (Klier and McMillen 2008) to 
better account for potential knowledge spillovers between related manufacturing businesses stemming from Detroit's core competency in automobile manufacturing. NAICS industry 32 corresponds to companies producing compounds that might be used in auto manufacturing such as plastics and rubber. NAICS industry 33 contains businesses engaged in raw materials, machinery, motor vehicle parts, and automobiles.

\section{Measuring Co-location}

To analyze the propensity for knowledge spillovers - operationalized in this study as the physical co-location between businesses - an index of co-location called the co-location quotient (CLQ) (Leslie and Kronenfeld 2010) is computed for multiple pairs of business activity. This index of co-location is analyzed in conjunction with kernel density maps for the three new types of business activity: new foreign firms, new domestic multi-establishment firms, and new domestic standalone firms. Pairing these analytical tools together is ideal because it provides complementary information; kernel density maps provide visual depictions about the intensity of business activity, but have no information about the statistical significance associated with the spatial patterns. The co-location quotient produces results with statistical significance, but lacks visually informative output like the kernel density maps.

The CLQ is an index that quantifies the extent that points of different types spatially colocate. Specifically, the CLQ quantifies the extent to which points in category A are likely to locate near points pertaining to category B (Leslie, Frankenfeld, and Makara 2012), and vice-versa. The index is computed similarly to the Location Quotient used in the regional science literature to assess regional concentrations of industrial activity (Leslie, Frankenfeld, and Makara 2012):

$$
C L Q_{A \rightarrow B}=\frac{C_{A \rightarrow B} / N_{A}}{N^{\prime}{ }_{B} /(N-1)}
$$


Where:

$\mathrm{N}=$ number of observations in each type of business considered in the analysis

$\mathrm{N}_{\mathrm{A}}=$ number of observations in business type $\mathrm{A}$

$\mathrm{N}^{\prime}{ }_{\mathrm{B}}=$ number of observations in business type $\mathrm{B}$

$\mathrm{C}_{\mathrm{A} \rightarrow \mathrm{B}}=$ number of type $\mathrm{A}$ points whose nearest neighbor is a type $\mathrm{B}$ point

Generally speaking, $C L Q_{A \rightarrow B}$ values less than 1 indicate that business points pertaining to category A are less likely to be located near business points pertaining to category B than a spatially random pattern would suggest, while a $C L Q_{A \rightarrow B}$ value greater than 1 indicates that type A points are more likely to be located near type B points than a spatially random pattern would suggest, given the proportion of type B points in the point distribution (Leslie and Kronenfeld 2010). The statistical significance associated with co-location quotient values is determined via Monte Carlo simulation (Leslie and Kronenfeld 2010).

Given the ability to discern the co-location tendencies between particular types of points, the co-location quotient is ideal for evaluating the location tendencies between different types of businesses at a micro-scale within metropolitan areas. In this analysis, new businesses of the three types (foreign, domestic standalone, and domestic multi-establishment) constitute the category A points measured against existing businesses in those same types as category B points. This creates nine individual combinations of $\mathrm{CLQ}_{\mathrm{A} \rightarrow \mathrm{B}}$ values for each year from 1990-2010. Since the colocation quotient represents a standardized measure of business type concentration, values can be compared over time and between different groups of points, which makes it particularly valuable in understanding evolutionary aspects of co-location behavior over time. Co-location results were computed with 15 nearest neighbors and 1,000 simulation runs in order to provide a robust definition of 'neighborhood' - if only the closest neighbors were used in this analysis, for example, the location tendencies of businesses slightly further away might not be captured. 


\section{Results}

In order to understand the evolution of firm location in the industries of interest, the general location of new firm activity is first analyzed via kernel density maps. New firm activity is emphasized here due to the importance of new businesses to regional economies (Wennekers and Thurik 1997; Carree and Thurik 2003). The co-location analysis follows, which considers the tendency of new firms to co-locate with existing businesses in the three categories of interest: foreign firms, multi-establishment domestic firms, and standalone domestic firms.

\subsection{Spatial Context}

In order to better understand the spatial patterns of new foreign, domestic multiestablishment, and domestic standalone manufacturing firms in Detroit over the study period, cumulative kernel density surfaces were estimated for new starts of each business type for each year (1990-2010). For each individual kernel density surface, the cell size was kept constant (approximately $.116 \mathrm{mi}^{2}$ ) in order to maintain a consistent grid from which to aggregate the density surfaces $^{2}$. All of the individual year-surfaces (e.g., 1990, 1991, 1992, etc.) by business type were then added together to create a set of cumulative kernel density surfaces that show concentrations of new start activity over the entire 21-year period.

Figure 2 shows the cumulative kernel density maps for new starts of foreign, domestic multi-establishment, and domestic standalone firms, with locations of major automotive company headquarters overlaid. Although these maps do not provide evidence of statistical significance, it is clear that from 1990-2010, new foreign firms cluster intensively near three auto company

\footnotetext{
2 The bandwidth used for each surface was "computed specifically to the input dataset using a spatial variant of Silverman's Rule of Thumb that is robust to spatial outliers" according to an algorithm in ArcMap version 10.3 (ArcGIS 2014).
} 
headquarters - Chrysler, Nissan, and Saturn. The strong new foreign business activity around these auto manufacturing headquarters - two of which are foreign-owned - lends credence to the second hypothesis, suggesting the influence of "enclave" effects on foreign firms' location decisions. The kernel density map for new domestic multi-establishment firms reflects a more diffuse pattern of location decisions than for foreign starts. The suburban Farmington/Northville cluster near the Nissan Technical Center remains a hotspot of activity, but there are also concentrations of new activity in a large triangle roughly defined by Chrysler headquarters in Auburn Hills, the Detroit suburb of Sterling Heights, and General Motors headquarters downtown. Domestic firms of both types, in fact, appear to locate in less concentrated patterns and are more likely to start within the city of Detroit itself.

\section{Figure 2 here}

For domestic standalone firms, higher densities of new starts are observed around the Saturn headquarters located in Troy. These observations are consistent with the nature and timing of Saturn's formation. Founded in the mid-1980s as a semi-autonomous arm of GM intended to compete with Japanese manufacturers, with a dedicated engineering staff, it is logical that new domestic standalone firms would start near GM's new venture, both to support Saturn and to induce and benefit from spillovers (Chappell 1998). In general, the map displays an even more diffuse pattern of location decisions than for domestic multi-establishment firms.

\subsection{Co-location of Businesses}

The co-location quotient is used to develop an understanding of the statistical propensity

for the different business types to locate near one another. This type of analysis provides a statistically significant value that characterizes the likelihood for two business types to locate 
nearby one another and is important to analyze because proximity is closely tied to opportunities for knowledge spillovers (Lamin and Livanis 2013). First, in order to better understand the connection between space and co-location (which is measured by proximity to neighbors), the average distance to neighboring business points of the same type for existing foreign, domestic standalone, and domestic multi-establishment firms was computed. Interestingly, foreign businesses became more clustered over the time period, moving from an average distance of 1.15 miles to the nearest foreign neighbor in 1990 to .72 miles in 2010 . Conversely, domestic firms became more dispersed - the average distance to the nearest neighbor of a domestic standalone firm moved from .15 miles in 1990 to .23 in 2010 , while the average distance to the nearest neighbor of a domestic multi-establishment firm increased from .27 miles in 1990 to .40 in 2010 . This indicates that foreign firms increased in density over the course of the study period, a finding which is echoed in the tight cluster of new foreign starts shown in Figure 2.

The small nearest neighbor distances in general - almost all under a mile - also indicate the close spatial proximity between businesses over the study period. Given prior work, which highlights the importance of spatial proximity to knowledge spillovers (Jaffe, Tratjenberg, and Henderson 1993; Anselin, Varga, and Acs 1997; Rosenthal and Strange 2003; Lamin and Livanis 2013), these small distances between neighboring businesses highlight the strong potential for knowledge spillovers within the manufacturing sector in Detroit.

Figure 3 presents the results of the co-location analysis for manufacturing (NAICS 32 and 33) business activity from 1990-2010. The specific hypotheses tested are indicated next to the label for each of the lines in each of the three charts. To evaluate the robustness of results, sensitivity analyses were conducted with respect to the number of nearest neighbors. The results in Figure 3 are robust to changes in the number of neighbors. Filled circles represent statistically-significant 
results with a p-value of .05 or less, while empty circles are not-significant ${ }^{3}$. The first panel in the figure focuses on the co-location behavior of new foreign firms with three types of existing businesses: existing foreign entities, existing domestic multi-establishment firms and existing domestic standalone firms. The second and third panels in the same figure illustrate the co-location behavior of new domestic firms and new multi-establishment firms (respectively) over time with the same three categories of existing business activity.

\section{Figure 3 here}

In every year of the study period, new foreign firms are more likely to locate near existing foreign firms than a random spatial distribution would suggest. At the same time, they are statistically more likely to be located near existing domestic multi-establishment firms. The colocation results show no spatial linkages between new foreign firms and domestic standalone firms. In fact, new foreign firms are less likely to co-locate near standalone domestic firms, as demonstrated by CLQ values less than one for every year in the study period. Combined, these results provide support for hypotheses one and two, which suggest a liability of foreignness and an enclave rationale to co-location behavior (respectively).

Interestingly, the co-location tendency between new foreign firms and existing foreign firms is higher than the co-location tendency between new foreign and existing domestic multiestablishment firms. This suggests that the enclave effect is perhaps more important to new foreign entities than the need to gain information from existing domestic multi-establishment firms. This higher co-location tendency with existing foreign entities could also reflect the declining dominance of domestically based auto manufacturers compared to foreign-based manufacturers

\footnotetext{
${ }^{3}$ Not-significant values were maintained in the graphs is order to maintain linear continuity.
} 
during this time period (Cutcher-Gershenfeld, Brooks, and Mulloy 2015). From this perspective, co-location near more competitive foreign enterprises may be an attempt to acquire knowledge from industry leaders over this time period.

The increasing co-location quotient values between new foreign firms and existing foreign firms over the study period provides evidence to reject hypothesis three. While it is not possible to ascertain the exact reasons for co-location, this increased likelihood of co-location over twentyone years suggests that industry leadership is driving the spatial proximity of foreign firms. On a year-to-year basis, the co-location behavior of new foreign firms (and the other types of new business activity) is quite dynamic. While informative, this dynamism suggests a need to evaluate general trends in co-location behavior over time rather than year-specific trends, which could prove misleading.

Surprisingly, the co-location behavior of new domestic multi-establishment firms is similar to that of new foreign firms, with some exceptions in times of economic distress. In terms of defining stress in the manufacturing industry, the declining market share of all big three automanufacturers compared to leading foreign competitors (Toyota and Honda), suggests that the study period could be viewed as a general period of distress for manufacturers; with peak levels of intensity towards the end of the study period between 2006 and 2009 that corresponds with the bailout of GM and Chrysler in 2008 (Cutcher-Gershenfeld, Brooks, and Mulloy 2015). Panel 2 of Figure 3 indicates that new branches of domestic multi-establishment firms co-locate with both existing domestic multi-establishment firms and existing foreign firms. However, the likelihood of new domestic multi-establishment co-location with existing foreign firms is higher than with other domestic multi-establishment firms; the co-location results indicate that in most years, new branches of domestic multi-establishment firms are 1.5 to 2 times more likely to locate with foreign 
firms than a spatially random distribution would suggest. For new domestic multi-establishment co-location with existing domestic multi-establishment firms, the co-location values are lower and range between 1 and 1.8. Thus, new branches of domestic multi-establishment firms are more likely to locate near foreign rather than domestic firms. These new branches did not exhibit a propensity to locate near existing domestic standalone firms. In fact, in later years of the study period, new branches were less likely to locate with this type of firm.

Combined, these results provide support for hypothesis four and suggest that new domestic multi-establishment firms may be attempting to learn from foreign competitors in times when U.S firms' practices left them at a competitive disadvantage. Thus, while Detroit remains an important innovation hub in manufacturing and related sectors (Hannigan, Cano-Kollmann, and Mudambi 2015), the co-location analysis suggests that foreign firms may be an increasingly important source of knowledge spillovers. These results are consistent with prior analyses of innovation activity, which highlight the internalization of patenting activity in this dynamic manufacturing cluster in the late 2000's (Hannigan, Cano-Kollmann, and Mudambi 2015) via international collaboration opportunities such as the Global Alliance for Hybrid Development located in the suburbs of Detroit in Troy, Michigan (New York Times 2006).

The third panel of Figure 3 presents the co-location results for new domestic standalone firms. These firms are included in the analysis given the importance of small businesses in generating employment (Birch 1987) and adding diversity to regional economies (Jacobs 1967; Frenken, Van Oort, and Verburg 2007). Surprisingly, new standalone domestic ventures do not co-locate near either existing domestic multi-establishment firms or existing foreign firms. They also display no tendency to co-locate near existing standalone businesses. Thus, analytical results provide evidence to reject hypothesis five: new standalone ventures do not have a tendency to 
locate near any of the existing venture types of interest in this study. There are several potential explanations for this comparative lack of co-location behavior. One explanation may be differences in cost-considerations for new domestic ventures and existing foreign and existing multi-establishment domestic firms. As highlighted in the kernel density maps, some key clusters of manufacturing activity are located in expensive locations within the metropolitan area (i.e. Troy, Michigan). The expense of office space in these locations may crowd out domestic firms who are less able to absorb the cost of locating in these clusters. As for the lack of co-location with existing domestic standalone firms, it is difficult to explain definitively why this is the case, since this type of co-location behavior represents an opportunity to gain access to knowledge spillovers at perhaps lower cost than would co-location with established, larger foreign and domestic multiestablishment firms. The outward expansion of business activity over time is perhaps the most likely explanation for a lack of co-location behavior. A comparison of the kernel density maps for the three different types of new firm activity, highlights the expansive nature of new domestic standalone activity over time compared to the other two new firm types.

\section{Discussion and Conclusion}

The goal of this study was to examine the co-location behavior of three different types of firms (foreign multinationals, domestic multi-establishment firms, and domestic standalone firms) in the Detroit metropolitan area over a twenty-one-year study period. This is important to study given prior work that suggests spatial proximity is important for knowledge spillovers (Jaffe, Tratjenberg, and Henderson 1993; Anselin, Varga, and Acs 1997; Rosenthal and Strange 2003) and that the location behavior of firms to access knowledge spillovers can provide insights about firm strategy (Lamin and Livanis 2013). This analysis is also key to understanding spatial clustering dynamics within Detroit, which is home to a world-famous hub of auto-manufacturing 
activity. As a study area, Detroit is important because it represents a location of deindustrialization activity over the last few decades that has retained its importance as a hub of innovative activity (Hannigan, Cano-Kollmann, and Mudambi 2015).

This paper tested five hypotheses using the co-location quotient (CLQ), which is a measure of the statistical propensity for particular types of firms to locate near one another in geographic space. In short, the results show that both new foreign and new domestic multi-establishment firms were more likely to co-locate near existing foreign ventures than would be expected by a spatially random distribution. The location behavior of new branches of domestic multi-establishment firms suggests a "catch-up" rationale, while the increasing co-location behavior of new foreign firms with existing foreign firms over time provides support for an enclave effect favoring existing foreign firms. New domestic standalone ventures do not co-locate near domestic multiestablishment firms or foreign multinationals. This is a surprising result, because small firms lack the resources of large firms, and might be expected to co-locate (Rigby and Brown 2015) to gain access to knowledge spillovers from larger firms' R\&D operations. Industry leaders might also be expected to physically attract new local ventures to enhance the likelihood of collaboration on projects (Cantwell and Mudambi 2011). This does not appear to be the case, and suggests even a crowding out effect for new local ventures. The CLQ analysis was also paired with visual output from kernel density maps to shed light on the intensity of spatial clusters. The kernel density maps highlight higher-intensity clusters of new foreign and new branches of multi-establishment firms compared to new standalone domestic firms.

Combined, these results suggest that the rationale for the co-location behavior observed for foreign firms is not related to a liability of foreignness, but rather the industry leadership of foreign firms during this time period. Salient support for this finding is provided by the co-location results 
for new branches of domestic multi-establishment firms, which are more likely to co-locate near existing foreign firms than existing domestic firms. These somewhat surprising results hint at an evolution in the manufacturing industry in Detroit. Historically, domestic firms were the leaders in the automobile industry, and suffered very little competition from foreign competitors until the 1970s. While prominent US auto manufacturers like GM and Ford survived this initial competition and continue to be important forces in the sector, industry leadership is now more nuanced and segmented by car size, class (economy vs. luxury), and use (light truck and SUV vs. sedan). Foreign firms have become innovators and industry leaders over time, out-competing U.S manufacturers in many of these segments.

However, there are some limitations to the present study. As with other studies, space is used a proxy for the ability to access knowledge spillovers, but does not ascertain whether firms actually receive these spillovers (Alcácer and Chung 2007). A second limitation is that information from firms is needed to understand the driving factors behind location decisions. To fully understand the receipt of knowledge spillovers and the rationale behind location decisions, survey and interview data are needed from firms. Secondary data is limited in this respect, as are conditional logit models in an intra-metropolitan context which suffer from an independence from irrelevant alternatives (IIA) problem. An interesting extension to this study would also involve an analysis of co-location behavior prior to 1990 to analyze co-location dynamics of firms when domestic manufacturers were the industry leaders in auto-manufacturing. This could reveal differences in the co-location behavior of both new foreign and new branches of domestic multiestablishment firms.

Nonetheless, this study has provided new insights into the dynamism behind firm colocation in the Detroit metropolitan area. One of these insights is the need for policy opportunities 
to involve new local ventures in Detroit based manufacturing activity, which appear to be crowded out of clusters of foreign multinational and large domestic firms. The second insight deals with the pull that foreign firms have on new foreign and new branches of established domestic firms: prior work has highlighted foreign firms in this cluster are innovating at higher rates and that more recently-established centers of excellence may be an explanation for this trend (Hannigan, CanoKollmann, and Mudambi 2015). This study provides spatial evidence to support these findings, which suggest that firms may be locating near increasingly innovative foreign firms to gain access to knowledge spillovers from industry leaders in the auto-manufacturing industry. Although U.S. automakers have experienced a revival since 2009 (Cutcher-Gershenfeld, Brooks, and Mulloy 2015), the mature state of the industry and the region's current status as a global center of innovation suggest opportunities for regional diversification based on auto industry oriented technological competencies to work towards an economic renaissance for the beleaguered regional economy. New domestic standalone ventures may be a path towards this renaissance, but they may require supportive policies to ensure their survival if they are to be an important factor in the evolution of this region.

\section{References}

Alcácer, Juan and Wilbur Chung. 2014. "Location strategies for agglomeration economies." Strategic Management Journal 35 (12): 1749-1761.

Almeida, Paul and Anupama Phene. 2004. "Subsidiaries and knowledge creation: The influence of the MNC and host country on innovation." Strategic Management Journal 25 (8-9): 847-864. 
Amadeo, Kimberly. 2016. “Auto Industry Bailout (GM, Ford, Chrysler): Was the Big 3 Bailout Worth It?" The Balance November 25, 2016 https://www.thebalance.com/auto-industry-bailoutgm-ford-chrysler-3305670

Anselin, Luc, Attila Varga, and Zoltan Acs. 1997. "Local geographic spillovers between university research and high technology innovations." Journal of Urban Economics 42 (3): 422448.

ArcGIS. 2014. "Kernel Density.” Accessed 2017. Retrieved from: http://desktop.arcgis.com/en/arcmap/10.3/tools/spatial-analyst-toolbox/kernel-density.htm.

Barrios, Salvador, Harry Huizinga, Luc Laeven, and Gaëtan Nicodème. 2012. "International taxation and multinational firm location decisions." Journal of Public Economics 96 (11): 946958.

Beugelsdijk, Sjoerd, Philip McCann, and Ram Mudambi. 2010. "Introduction: Place, space and organization-economic geography and the multinational enterprise." Journal of Economic Geography 10 (4): 485-493.

Birch, D. 1987. Job Creation in America: How Our Smallest Companies Put the Most People to Work. New York, NY: The Free Press. 
Bosma, Niels, André Van Stel, and Kashifa Suddle. 2008. "The geography of new firm formation: Evidence from independent start-ups and new subsidiaries in the Netherlands." International Entrepreneurship and Management Journal 4 (2): 129-146.

Buettner, Thiess and Martin Ruf. 2007. "Tax incentives and the location of FDI: Evidence from a panel of German multinationals." International Tax and Public Finance 14 (2): 151-164.

Cantwell, John. 1989. Technological innovation and multinational corporations. Cambridge, MA: B. Blackwell.

Cantwell, John and Ram Mudambi. 2011. "Physical attraction and the geography of knowledge sourcing in multinational enterprises." Global Strategy Journal 1 (3-4): 206-232.

Carlsson, Bo and Ram Mudambi. 2003. "Globalization, entrepreneurship, and public policy: a systems view." Industry and Innovation 10 (1): 103-116.

Carree, M.A. and A.R. Thurik. 2003. “The Impact of Entrepreneurship on Economic Growth.” In Handbook of Entrepreneurship Research, edited by Z.J. Acs and D.B. Audretsch, 437-471.

Chappell, Lindsay. 1998 “GM Plans to Swallow Another Slice of Saturn.” Automotive News. August 24, 1998.

http://www.autonews.com/article/19980824/ANA/808240743/gm-plans-to-swallow-anotherslice-of-saturn Accessed March 14, 2017. 
Chung, Wilbur and Jaeyong Song. 2004. "Sequential investment, firm motives, and agglomeration of Japanese electronics firms in the United States." Journal of Economics \& Management Strategy 13 (3): 539-560.

Chang, Sea Jin and Dean Xu. 2008. "Spillovers and competition among foreign and local firms in China." Strategic Management Journal 29 (5): 495-518.

Coombs, Joseph, Ram Mudambi, and David L. Deeds. 2006. "An examination of the investments in US biotechnology firms by foreign and domestic corporate partners." Journal of Business Venturing 21 (4): 405-428.

Cutcher-Gershenfeld, Joel, Dan Brooks, and Martin Mulloy. 2015. "The Decline and Resurgence of the U.S. Auto Industry. Economic Policy Institute Briefing paper no. 399. Accessed October 2016. Retrieved from: http://www.epi.org/publication/the-decline-and-resurgence-of-the-u-sauto-industry.

Dunning, John. 1977. "Trade, location of economic activity and the MNE: A search for an eclectic approach." In The International Allocation of Economic Activity, pp. 395-418. Palgrave Macmillan UK.

Dunning, John. 1988. "The eclectic paradigm of international production: A restatement and some possible extensions." Journal of International Business Studies 19(1): 1-31. 
Frenken, K., F. Van Oort, and T. Verburg. 2007. "Related Variety, unrelated variety and regional economic growth." Regional Studies 41 (5): 685-697.

Friedman, Joseph, Daniel Gerlowski, and Johnathan Silberman. 1992. "What attracts foreign multinational corporations? Evidence from branch plant location in the United States." Journal of Regional Science 32 (4): 403-418.

Glaeser, Edward and William Kerr. 2009. "Local industrial conditions and entrepreneurship: how much of the spatial distribution can we explain?." Journal of Economics \& Management Strategy 18 (3): 623-663.

Glaeser, Edward, William Kerr, and Giacomo Ponzetto. 2010. "Clusters of entrepreneurship." Journal of Urban Economics 67 (1): 150-168.

HBS. 2014. Cluster Mapping Methodology. Harvard Business School and the U.S. Economic Development Administration. http://clustermapping.us/content/cluster-mapping-methodology

Hannigan, Thomas, Marcelo Cano-Kollmann, and Ram Mudambi. 2015. "Thriving innovation amidst manufacturing decline: The Detroit auto cluster and the resilience of local knowledge production." Industrial and Corporate Change 24 (3): 613-634.

Jacobs, Jane. 1967. The Economy of Cities. New York: Random House. 
Jaffe, Adam B., Manuel Trajtenberg, and Rebecca Henderson. 1993. Geographic localization of knowledge spillovers as evidenced by patent citations. The Quarterly journal of Economics 108 (3): 577-598.

Jofre-Monseny, Jordi, Raquel Marín-López, and Elisabet Viladecans-Marsal. 2011. "The mechanisms of agglomeration: Evidence from the effect of inter-industry relations on the location of new firms." Journal of Urban Economics 70 (2): 61-74.

Kappen, Philip. 2011. "Competence-creating overlaps and subsidiary technological evolution in the multinational corporation." Research Policy 40 (5): 673-686.

Klier, Thomas and Daniel McMillen. 2008. "Evolving agglomeration in the US auto supplier industry." Journal of Regional Science 48 (1): 245-267.

Lamin, Anna and Grigorios Livanis. 2013. "Agglomeration, catch-up and the liability of foreignness in emerging economies." Journal of International Business Studies 44 (6): 579-606.

Leslie, Timothy, Cara Frankenfeld, and Matthew Makara. 2012. "The spatial food environment of the DC metropolitan area: Clustering, co-location, and categorical differentiation." Applied Geography 35 (1): 300-307.

Leslie, Timothy and Barry Kronenfeld. 2011. "The co-location quotient: A new measure of spatial association between categorical subsets of points." Geographical Analysis 43 (3): 306326. 
Marshall, Alfred. 1920. Principles of Economics. Macmillan: London.

McCann, Philip and Ram Mudambi. 2005. "Analytical differences in the economics of geography: the case of the multinational firm." Environment and Planning A 37 (10): 1857-1876.

Meyer, Klaus, Ram Mudambi, and Rajneesh Narula. 2011. "Multinational enterprises and local contexts: The opportunities and challenges of multiple embeddedness." Journal of Management Studies 48 (2): 235-252.

Mudambi, Ram. 1995. "The MNE investment location decision: some empirical evidence." Managerial and Decision Economics 16 (3): 249-257.

Narula, Rajneesh and Grazia Santangelo. 2009. "Location, co-location and R\&D alliances in the European ICT industry." Research Policy 38 (2): 393-403.

Narula, Rajneesh and Grazia Santangelo. 2012. "Location and co-location advantages in international innovation." Multinational Business Review 20 (1): 6-25.

New York Times. 2006. “GM, BMW and Daimler pool efforts on hybrids.” Accessed 2017. Retrieved from: http://www.nytimes.com/2006/08/11/business/worldbusiness/11ihthybrid.2451448.html?.r=1\&. 
Nissan. 2016. “Corporate Info.” Accessed 2016. Retrieved from:

http://www.nissanusa.com/about/corporate-info.

Rigby, David L., and W. Mark Brown. 2015 "Who benefits from agglomeration?." Regional Studies 49 (1): 28-43.

Rosenthal, S.S. and W.C. Strange. 2001. "The determinants of agglomeration." Journal of Urban Economics 50(2): 191-229.

Schotter, Andreas and Paul Beamish. 2013. "The hassle factor: An explanation for managerial location shunning." Journal of International Business Studies 44 (5): 521-544.

Stinchcombe, Arthur L. 1965 "Social structures and organizations." In James G. March (ed.), Handbook of Organizations: 142-193. Chicago: Rand McNally.

Visteon. 2017. "Visteon Locations." Accessed 2017. Retrieved from: http://www.visteon.com/worldwide/locations.htm.

Walls \& Associates. 2013. "National Establishment Time-Series (NETS) Database: 2012 Database Description.” Accessed 2016. Retrieved from: http://bit.ly/297UF34.

Weber, Peter. 2013. "The rise and fall of Detroit: A timeline.” The Week. July 19, 2013. Accessed 2016. Retrieved from: http://theweek.com/articles/461968/rise-fall-detroit-timeline. 
Wennekers, S. and R. Thurik. 1999. "Linking Entrepreneurship and Economic Growth.” Small Business Economics 13(1): 27-55.

Zaheer, Srilata. 1995. "Overcoming the liability of foreignness." Academy of Management Journal 38 (2): 341-363.

Zaheer, Srilata. 2002. "The liability of foreignness, redux: A commentary." Journal of International Management 8 (3): 351-358. 


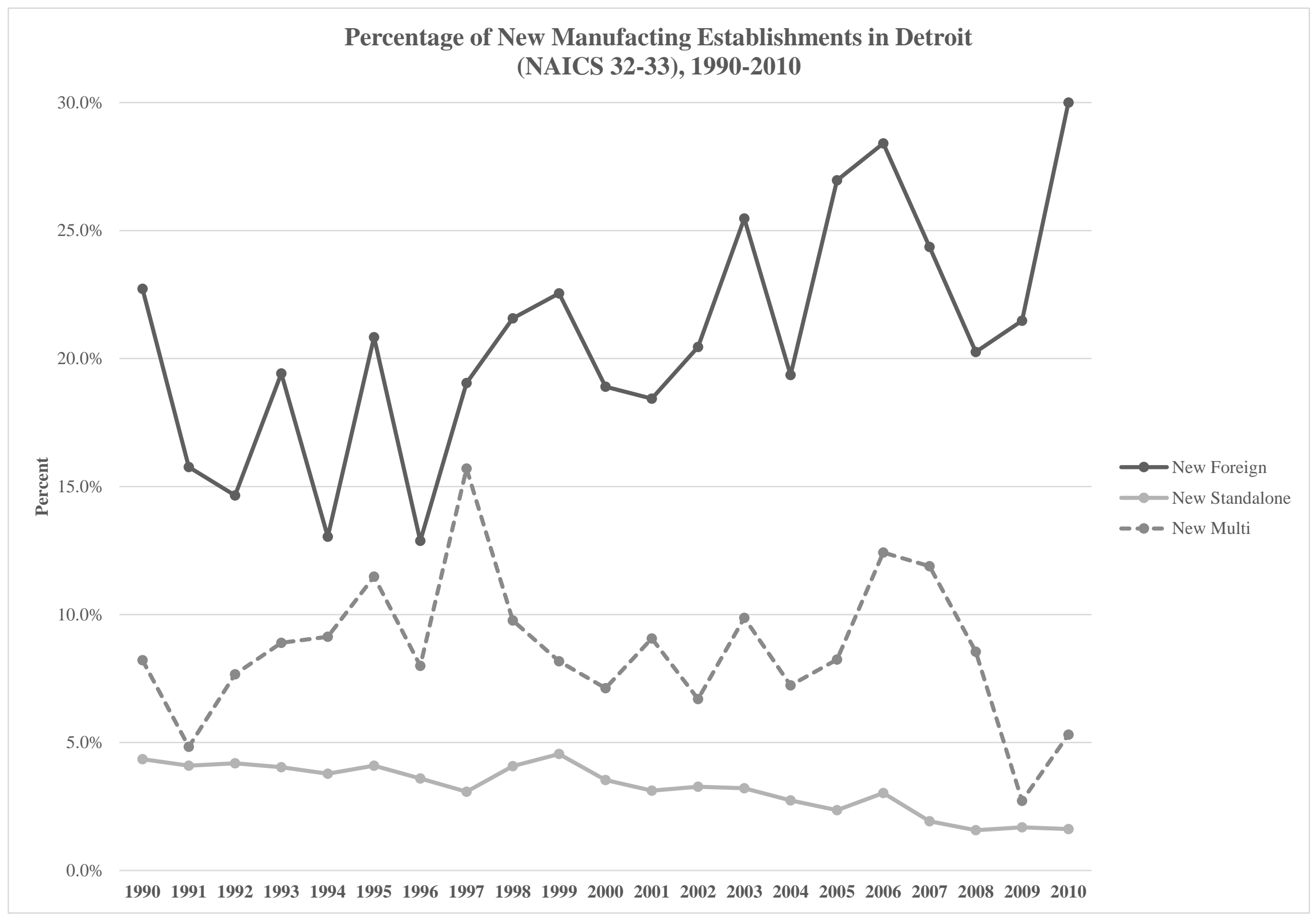

Figure 1. Percentage of new establishments in Detroit in manufacturing (NAICS 32-33), 1990-2010. 

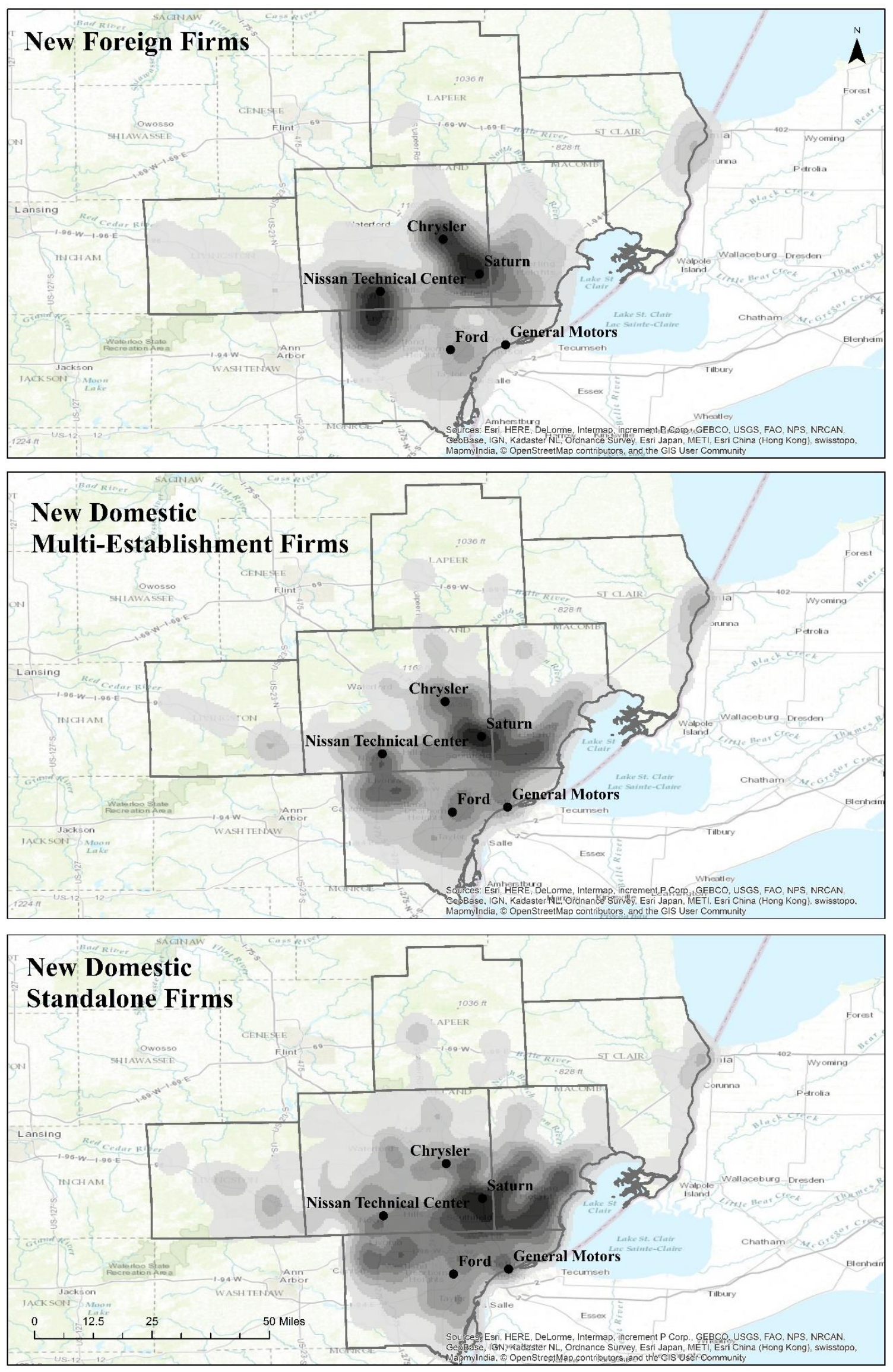

Figure 2. Cumulative kernel density maps for new business starts and locations of major automotive company headquarters, $1990-2010^{\mathrm{i}}$ 

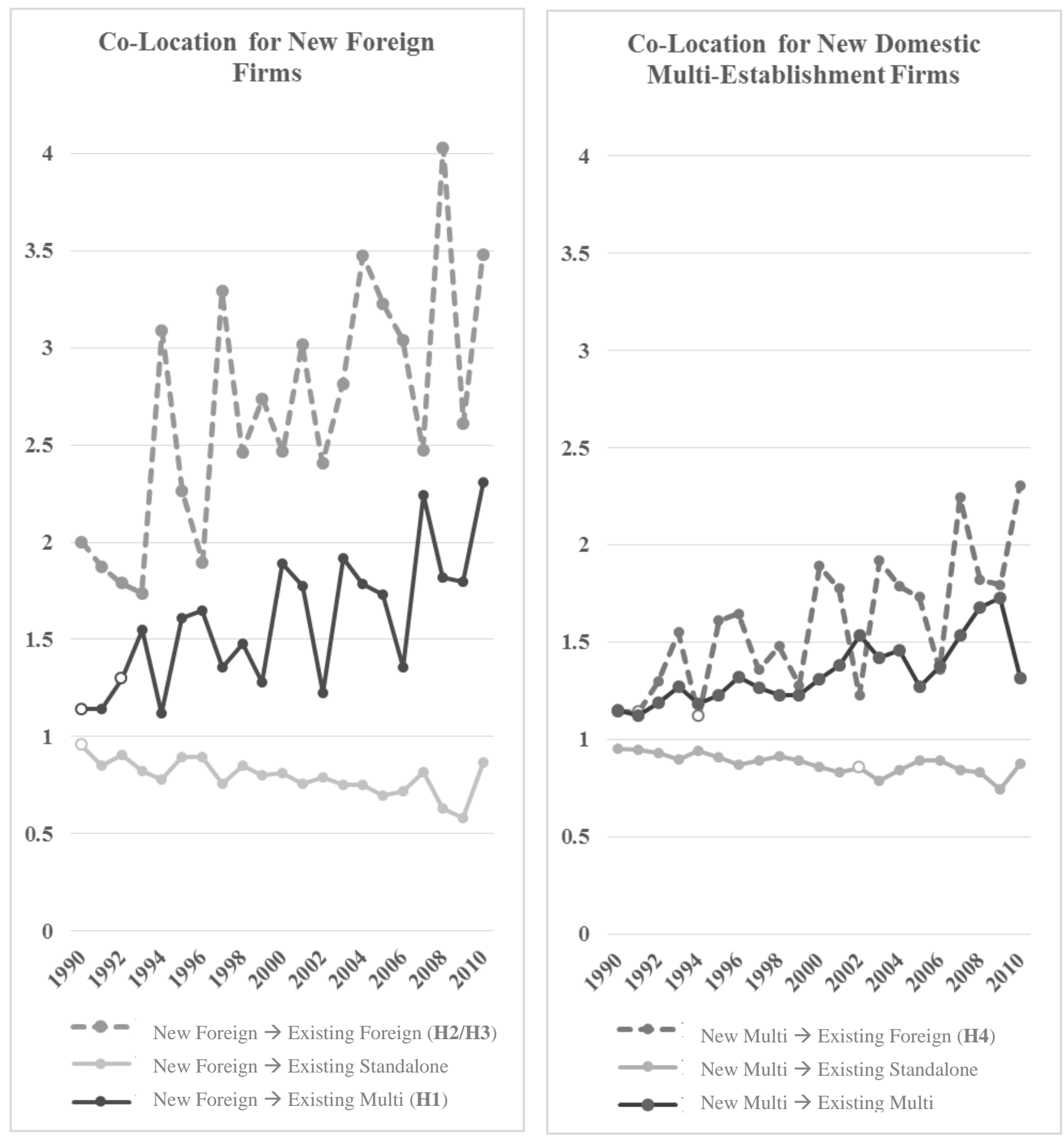


\begin{abstract}
' Note: the symbology for kernel density values for each of these three maps are not the same. For instance, due to the much larger total number of new domestic standalone firms, the largest cell value for that business type is 95,377 compared to 5,685 for new foreign firms. Since the intent of this map is to compare spatial concentrations and not overall values, each was displayed according to its own 10-class Jenks natural breaks classification. This also allows for the observation of significant variation within each business type.
\end{abstract}

